\section{Transfusion-associated graft-versus-host disease: A concise review}

\author{
Palma Manduzio \\ Diagnostic Department, Clinical \\ Pathology, 'Augusto Murri' Civil \\ Hospital of Fermo, Italy
}

\begin{abstract}
Transfusion-associated graft-versushost disease (TA-GVHD) represents a rare fatal event observed in immunocompromised patients and immunocompetent individuals. The main clinical features of this transfusion reaction are pancitopenia and multiorgan failure (skin, liver, gut). The possible pathogenesis includes donor $\mathrm{T}$ lymphocyte proliferation in blood, their engraftment and host tissue attack. The purpose of this narrative review was analyzing the international guidelines for irradiation of cellular blood components to prevent TA-GVHD. A literature search was conducted using PubMed articles published between January 2000 to July 2018. American, Australian, British and Japanese transfusion guidelines have been compared regarding clinical indications. The contribution of manuscripts has been focused on recipients of Haematopoietic Stem Cell Transplantation, severe cellular immunodeficient patients, fetuses and neonates, immunocompentent individuals. Furthermore, 348 cases of TA-GVHD in the last five decades have been documented according to a recent systematic review. The standard of care to prevent this complication is gamma or $\mathrm{x}$ irradiation of cellular blood products. New treatments with pathogen inactivation appear safe and effective against proliferating white blood cells and T cells. Further clinical and biological studies are necessary to better characterize immunocompetence of $\mathrm{T}$ cells and select alternative preventive strategies.
\end{abstract}

\section{Introduction}

Cellular blood products which include red blood cells (RBC), platelets (PLT), granulocyte units and non-frozen plasma carry the risk for TA-GVHD. ${ }^{1,2}$ This transfusion complication is documented in immunocompromised patients and in immunocompetent individuals. ${ }^{1-3}$ Clinical features of the reaction include erythema, diarrhea, hepatitis, aplasia which occurred more commonly within 1-2 weeks of trans- fusion history. Laboratory features include pancytopenia, elevated alkaline phosphatase, increased transaminases and elevated bilirubin. A suggestive skin, liver or gut biopsy may recognize mononuclear infiltrates of lymphocytes. The possible pathogenesis includes donor $\mathrm{T}$ lymphocyte proliferation in blood components, their engraftment and host tissue attack (skin, liver, gut and bone marrow). ${ }^{4,6}$

Chimerism or engraftment analysis of $\mathrm{T}$ lymphocytes through molecular assays (e.g. short tandem repeats analysis or a variable number of tandem repeat studies) may be helpful in case of suspect of the syndrome. ${ }^{7,8}$ Alternatively, fluorescent in situ hybridization for the $\mathrm{X}$ and $\mathrm{Y}$ chromosomes may be considered in case of sex-mismatched between donor and recipient. ${ }^{9}$

TA-GVHD cases has been reported in immunodeficient recipients (newborn, hematological patients, recipient of haematopoietic stem cell transplantation) and in immunocompetent individuals who receive blood components from a family member (donor and recipient were partially matched for Human Leucocyte Antigen (HLA)) or in Japanese population (in which high degree of homozygosity of HLA has been documented). ${ }^{1-9}$ Interestingly, no reports of the reaction has been noted in acquired immunodeficiency syndrome (AIDS) probably because the donor lymphocytes are not able to survive and proliferate adequately in this recipient and initiate the immune response which results in host tissue attack. ${ }^{10}$ Certainly, unknown mechanisms may be involved in its pathogenesis. ${ }^{1-9}$ The focus of this review was the analyis of the international guidelines for irradiation of blood components for clinical practice. ${ }^{11-16}$ New data are recently published regarding alternative preventive methods. ${ }^{17,18}$

\section{Methods and Results}

The purpose of this narrative review was analyzing the international guidelines for irradiation of blood components to prevent TA-GVHD. ${ }^{11-16} \mathrm{~A}$ literature search was conducted using Pub Med for articles published from January 2000 to July 2018 using the terms TA-GVHD and guidelines for irradiation of cellular blood productsand TA-GVHD and systematic review. Only articles published in English were considered. The contribution of manuscripts was focused on recipients of Haematopoietic Stem Cell Transplantation (HSCT), severe cellular immunodeficient patients, fetuses and neonates, immunocompetent individuals. The results were
Correspondence: Palma Manduzio, Diagnostic Department, Clinical Pathology, 'Augusto Murri' Civil Hospital of Fermo, Via A. Murri 21, 63900 Fermo (FM), Italy. Tel.: +39.0734.6252230 - Fax: +39.0734.6252226. E-mail: ina.m77@alice.it

Key words: Transfusion-associated graft-versus-host disease, cellular blood products, irradiation, $\mathrm{T}$ lymphocytes, immunodeficiency.

Acknowledgements: The author express appreciation to all the laboratory team of Clinical Pathology of Fermo (Italy), in particular Dr Licitra Salvatore (Chief at Clinical Laboratory), Dr Bubbolini Mario, Dr Paci Ornella Onorina, Dr Vallorani Sarah, Dr Arduini Alessandra. The author thanks Dr Loggi Elisabetta for her assistance with the literature and Dr Clementina Fraticelli, Directory of Camerino University Library (Macerata). The author is grateful to Dr Pauri Paola, Chief at Clinical Pathology of Jesi (Ancona) and Dr Zaccaria Alfonso, Chief at Hematology Unit of Ravenna for their mentorship.

Conflict of interest: the author declares no competing interests.

Funding: none

Received for publication: 17 April 2018.

Revision received: 4 October 2018.

Accepted for publication: 17 July 2018.

This work is licensed under a Creative Commons Attribution-NonCommercial 4.0 International License (CC BY-NC 4.0).

(C) Copyright P. Manduzio, 2018

Licensee PAGEPress, Italy

Hematology Reports 2018; 10:7724

doi:10.4081/hr 2018.7724

complemented by clinical experience.

Characteristics of irradiated cellular blood products according to the international guidelines are summarized in Table 1.1116 Clinical indications and controversies regarding possible benefit of irradiation policy are discussed in Tables 2 and 3, respectively. ${ }^{11-16}$

\section{Recipients of haematopoietic stem cell transplantation}

In allogenic hematopoietic stem cell transplantation (HSCT) irradiation of blood components must be started at a least 7 days prior HSCT (the time of initiation of conditioning regimen) and continued until 6 or 12 months after the procedure or until lymphocytes is more than $1 \times 10^{9} / \mathrm{L}$. This caution 
should be considered indefinitely in case of chronic graft-versus-host-disease or evidence of immune derangement according to the British, Australian and American guidelines. ${ }^{11-16,19}$ In similar manner, irradiation of RBC or PLT units must be started at a least
7 days prior autologous HSCT (the time of initiation of conditioning regimen) until 3 months after the procedure or 6 months in case of total body irradiation conditioning. ${ }^{11-16,20}$ Importantly, immune reconstitution is recognized a complex and multistep phenomenon in allogenic and autologous hematopoietic stem cell transplantation. ${ }^{21,22}$ In fact, only a quantitative analyisis may be performed by flow cytometry. 5,23

Table 1. International guidelines for irradiation of cellular blood products, main features.

\begin{tabular}{|c|c|c|c|c|}
\hline Main features & $\begin{array}{l}\text { American (New York) } \\
2012\end{array}$ & $\begin{array}{l}\text { British } \\
2011\end{array}$ & $\begin{array}{l}\text { Australian and New } \\
\text { Zealand } 2011\end{array}$ & Japanese 2000 \\
\hline Blood product & $\begin{array}{l}\text { All blood components } \\
\text { should be irradiated } \\
\text { with the exception of } \\
\text { frozen RBC and frozen } \\
\text { plasma and their products, } \\
\text { peripheral blood stem cells. } \\
\text { Bone marrow, cord blood, } \\
\text { donor lymphocytes }\end{array}$ & $\begin{array}{l}\text { - RBC may be irradiated } \\
\text { at any time up to } 14 \text { days after } \\
\text { collection and must stored } \\
\text { for a further } 14 \text { days } \\
\text { - PLT can be irradiated at any } \\
\text { stage during storage } \\
\text { - Granulocyte should be } \\
\text { irradiated and transfused } \\
\text { as soon as possible }\end{array}$ & $\begin{array}{l}\text { - RBC may be irradiated at any time } \\
\text { up to } 14 \text { days after collection } \\
\text { and must stored for a further } 14 \text { days } \\
\text { - PLT can be irradiated at any } \\
\text { stage during storage } \\
\text { - Granulocyte should be irradiated } \\
\text { and transfused as soon as possible }\end{array}$ & $\begin{array}{l}\text { All blood components } \\
\text { should be irradiated } \\
\text { with the exception } \\
\text { of frozen plasma and } \\
\text { their products }\end{array}$ \\
\hline $\begin{array}{l}\text { Irradiation type } \\
\text { and dose }\end{array}$ & 25 Gy & $\begin{array}{l}\text { Gamma or X irradiation of } \\
25 \text { Gy, no more than } 50 \text { Gy }\end{array}$ & Gamma or X irradiation of $25 \mathrm{~Gy}$ & $\begin{array}{l}15-50 \text { Gy, } \\
\text { no more than } 50 \text { Gy }\end{array}$ \\
\hline
\end{tabular}

RBC (red blood cells), PLT (platelets), Gy (Gray).

Table 2. International guidelines for irradiation of cellular blood components, clinical indications.

\begin{tabular}{|c|c|c|c|c|}
\hline Main features & $\begin{array}{l}\text { American (New York) } \\
2012\end{array}$ & $\begin{array}{l}\text { British } \\
2011\end{array}$ & $\begin{array}{l}\text { Australian and New } \\
\text { Zealand } 2011\end{array}$ & $\begin{array}{l}\text { Japanese } \\
2000\end{array}$ \\
\hline $\begin{array}{l}\text { Recipient of } \\
\text { allogenic HSCT }\end{array}$ & Indication & $\begin{array}{l}\text { - Irradiated blood components } \\
\text { must be started } 7 \text { days prior } \\
\text { HSCT until } 6 \text { months } \\
\text { post-transplant or } \\
\text { lymphocytes }>1 \times 10^{9} / \mathrm{L} \\
\text { - Indefinitely in case }\end{array}$ & $\begin{array}{l}\text { Irradiated blood components } \\
\text { must be continued until } 12 \\
\text { months post-transplant or } \\
\text { lymphocytes }>1 \times 10^{9} / \mathrm{L}\end{array}$ & Indication \\
\hline
\end{tabular}

\begin{tabular}{|c|c|c|c|c|}
\hline $\begin{array}{l}\text { Recipient of } \\
\text { autologous HSCT }\end{array}$ & Indication & $\begin{array}{l}\text { Irradiated blood components } \\
\text { should be started } 7 \text { days } \\
\text { prior HSCT until } 3 \text { months } \\
\text { or } 6 \text { months in case of TBI } \\
\text { conditioning regimen }\end{array}$ & $\begin{array}{l}\text { Irradiated blood components } \\
\text { must be started } 7 \text { days } \\
\text { prior HSCT until } 3 \text { months or } 6 \text { months } \\
\text { in case of TBI conditioning regimen }\end{array}$ & Indication \\
\hline $\begin{array}{l}\text { Autologous stem } \\
\text { cell harvesting }\end{array}$ & Indication & $\begin{array}{l}\text { Irradiated blood components should } \\
\text { be started } 7 \text { days prior autologous } \\
\text { stem cell harvesting }\end{array}$ & Indication & No data reported \\
\hline $\begin{array}{l}\text { Congenital T cell } \\
\text { immunodeficiencies }\end{array}$ & Indication & Indication in all severe syndromes & Indication & Indication \\
\hline $\begin{array}{l}\text { Aplastic Anemia } \\
\text { and anti-thymocyte } \\
\text { globulin }\end{array}$ & Indication & Until lymphocyte $>1 \times 10^{9} / \mathrm{L}$ & Possible indication & Indication \\
\hline Hodgkin Lymphoma & Indication & Indefinitely & $\begin{array}{l}\text { Indication for at least } 2 \text { years } \\
\text { after successful treatment } \\
\text { or indefinitely }\end{array}$ & Indication \\
\hline Purine analougeus & Indication & Indefinitely & Indication for at least 1 year or indefinitely & Indication \\
\hline Alentuzumab & Indication & $\begin{array}{l}\text { Indication includes hematological } \\
\text { and autoimmune diseases }\end{array}$ & Indication & Indication \\
\hline $\begin{array}{l}\text { Intrauterine } \\
\text { transfusion (IUT), } \\
\text { exchange transfusion } \\
\text { (ET), neonatal } \\
\text { alloimmune } \\
\text { thrombocytopenia } \\
\text { (NAIT) }\end{array}$ & $\begin{array}{l}\text { Blood for IUT and } \\
\text { ET should be irradiated }\end{array}$ & $\begin{array}{l}\text { - Blood for IUT should be } \\
\text { irradiated until } 6 \text { months } \\
\text { after expected date of delivery } \\
\text { - Blood for ET after IUT } \\
\text { should be irradiated until } \\
6 \text { months after birth } \\
\text { - RBC less than } 5 \text { days of age should } \\
\text { be used for IUT or ET and transfused } \\
\text { within } 24 \text { hours of irradiation }\end{array}$ & $\begin{array}{l}\text { - Blood for IUT and ET } \\
\text { must be irradiated } \\
\text { - Platelets must be irradiated } \\
\text { to treat NAIT until } 6 \text { months } \\
\text { after birth }\end{array}$ & $\begin{array}{l}\text { Neonates require ET } \\
\text { should receive } \\
\text { irradiated } \mathrm{RBC}\end{array}$ \\
\hline $\begin{array}{l}\text { Cellular blood } \\
\text { components from } \\
\text { relatives }\end{array}$ & Indication & Indication & Indication & Indication \\
\hline
\end{tabular}

HSCT (hematopoietic stem cell transplantation), GVHD (graft-versus-host disease), TBI (total body irradiation), IUT (intrauterin transfusion), ET (exchange transfusion), NAIT (neonatal alloimmune thrombocytopenia). 


\section{Severe cellular immunodeficient patients}

Neonates and infants must receive, definitely, irradiated blood components in case of congenital $T$ cell immunodeficiencies or before a confirmed diagnosis. ${ }^{11-14}$

Aplastic anemia treated with antithymocyte globulin must receive irradiated transfusions according to all analized guidelines. ${ }^{11-15}$

In case of Hodgkin Lymphoma, a significantly T-cell immunosuppressed disease, all international guidelines confirm that patients should receive irradiated cellular blood components for at least 2 years following successful treatment or indefinitely according to the British and Australian guidelines, respectively. ${ }^{11-15}$

In similar manner, patients treated with alemtuzumab or purine analogues (fludarabine, cladribrine, deoxycoformicin, bendamustine and clofarabine), represent another mandatory indication of the irradiation of blood components for 1 year or longer (following successful treatment). ${ }^{11-15}$

\section{Fetuses and neonates}

Irradiation of blood products is recommended for intrauterine transfusion (IUT) according to the international guidelines. ${ }^{11-}$ $14,24,25$ On the other hand, indication of irradiation of red blood cells for exchange transfusion (ET) after IUT varies in different countries. ${ }^{11-14,24.25}$

In line with the international guidelines RBC less than 5 days of age must be used for IUT or ET and transfused within 24 hours of irradiation to reduce the risk of increased serum potassium level. ${ }^{11-14}$ The IUT is an invasive procedure performed for the treatment of fetal anemia frequently due to severe haemolytic disease of the fetus and newborn (HDFN) due to maternal alloimmune antibodies against red cell antigens of fetus (more commonly Rh, Kell, Duffy, Kidd and MNSs antigens) or parvovirus infection. The ET is a procedure performed to treat resistant icterus due to HDFN or severe anemia. Furthermore, Australian guidelines underline the importance of irradiated platelets in neonatal alloimmune thrombocytopenia (NAIT). ${ }^{11}$ This complication is due to maternal alloimmune antibodies against platelet antigens of fetus, more commonly against human platelet antigen 1a (HPA-1a).
Prematures and low-birth weight babies may represent a possible high-risk category according to several expert opinions and guidelines. ${ }^{24,25}$ Open question regards how long this caution should be considered after birth due to the possible immature thymus dysfunctions. ${ }^{6,26}$ Briefly, the majority of guidelines suggest that irradiation policy should be continued for at least 6 months after birth. ${ }^{11-14}$

\section{Immunocompetent individuals and other risk categories}

Irradiation of cellular blood products is recommended for immuncompetent individuals who receive cellular blood components from relatives according to the international guidelines. ${ }^{11-14}$ For clinical standpoint is mandatory the appropriate indications and use of blood products, avoid transfusions from first and second relatives.

A systematic review of 348 cases published by Kopolovic, which includes all cases published in the last 5 decades without restriction of language, confirm that a small percentage (more specifically $5 \%$ ) of the cases appears in non-high risk setting according to the current guidelines. ${ }^{27}$

Few data regard the minimum number

Table 3. International guidelines for irradiation of cellular blood products, controversies.

\begin{tabular}{|c|c|c|c|}
\hline Diagnosis or treatment & British 2011 & Australian and New Zealand 2011 & Japanese 2000 \\
\hline Acute Leukemia & No indication & Possible indication & Possible indication \\
\hline Chronic Myeloid Leukemia & No data reported & Possible indication & No data reported \\
\hline Haemophilia and thalassemia & No data reported & No indication & No data reported \\
\hline Massive transfusions & No data reported & Possible indication & Indication \\
\hline Cardiovascular surgery & No indication & Possible indication & Indication \\
\hline Solid organ tranplantation & $\begin{array}{l}\text { No indicated unless } \\
\text { alentuzumab use }\end{array}$ & No indication & $\begin{array}{l}\text { Indication in } \\
\text { immunocompromised recipients }\end{array}$ \\
\hline Solid tumors & No indication & No indication & $\begin{array}{l}\text { - } \text { Chemotherapy } \\
\text { or radiotherapy in solid tumor } \\
\text { - } \text { Surgical operation for cancers }\end{array}$ \\
\hline Non-hodgkin Lymphoma & No indication & $\begin{array}{l}\text { It may be a possible indication } \\
\text { in lymphopenic (lymphocytes } \\
<0.5 \times 10^{9} / \mathrm{L} \text { ) patients who receive } \\
\text { chemotherapy or radiotherapy }\end{array}$ & Possible indication \\
\hline T cell Lymphoma & No data reported & Possible indication & No data reported \\
\hline Rituximab & No indication & No indication & No data reported \\
\hline High dose steroids & No data reported & Possible indication & Indication \\
\hline Acquired immunodeficiency syndrome & No indication & No indication & No data reported \\
\hline Elderly & No data reported & No data reported & $\begin{array}{l}\text { Indication in recipient of blood } \\
\text { transfusion of }>65 \text { years old }\end{array}$ \\
\hline $\begin{array}{l}\text { Premature babies and } \\
\text { low-birth weight babies }\end{array}$ & No data reported & $\begin{array}{l}\text { Prematures babies ( }<28 \text { weeks) } \\
\text { and low-weight babies }(<900 \mathrm{gr}) \\
\text { may be a possible indication for } \\
\text { at least } 7 \text { months }\end{array}$ & $\begin{array}{l}\text { Low-weight babies may be } \\
\text { a possible indication }\end{array}$ \\
\hline
\end{tabular}


of lymphocytes necessary to cause TAGVHD. ${ }^{11,12}$ According to Kopolovic and colleagues, cellular blood components involved in this fatal complication were whole blood $\left(2 \times 10^{9}\right.$ lymphocytes per unit), ${ }^{28}$ leukoreduced components $\left(5 \times 10^{6}\right.$ lymphocytes per unit) ${ }^{28}$ and component age inferior to 48 hours. ${ }^{27}$

Furthermore, this review underlines that HLA antigens shared by the recipient were responsible of TA-GVHD observed in immunocompent recipient because donor lymphocytes of similar HLA are not recognized as foreign and destroyed by the immune system of recipient. ${ }^{27}$

\section{Discussion}

A significant decrease of this complication has been noted in Japan since the introduction of irradiation in $1998 .{ }^{29}$ In addition, only 2 fatal TA-GVHD were recognized in UK from 1999 to $2013 .{ }^{30}$ In similar manner, 3 fatal events were documented in USA from 2005 to 2013 . $^{6}$

Gamma or X irradiation of blood products is considered the gold standard to prevent the complication due to the capability of damage DNA of white blood cells (WBC). ${ }^{1-14}$ The maximum expiration time of red blood cell post-irradiation varies from 28 to 14 days according to the American and British Standards, respectively. ${ }^{16,30}$

New preventive treatments with pathogen inactivation appear effective against proliferating $\mathrm{WBC}$ and $\mathrm{T}$ cells and useful to treat all cellular blood products (RBC, platelets, whole blood, plasma). More recently, Fast L. summarized the main technologies (e.g. solvent detergent, methylene blue, UV-light etc) which interfere with the replication of pathogens and leucocytes through nucleic acid modifications. ${ }^{18}$ Furthermore, a large prospective study was recently published regarding transfusion of platelet components prepared with amotosalen-UVA photochemical treatment. ${ }^{19}$

Limits of irradiation of RBC products include reduction of the expiration date and the increase of its cost. In addition, RBC irradiation is time consuming, rises the serum potassium level and causes hemolysis therefore it favors possible complications in neonates, renal failure or in massive transfusions. ${ }^{1,6,31}$ No modification of expiration date or quality of platelet units have been recognized. ${ }^{32}$ Limits of new technologies are the paucity of data regarding the long-term follow-up. ${ }^{18,19}$

Controversies regard which cellular blood products are more commonly involved in the reaction and additional possible risk categories for TA-GVHD remain after literature search. ${ }^{11-14}$ Granulocyte units, which contain more lymphocytes $\left(10 \times 10^{9}\right.$ lymphocytes per unit), ${ }^{28}$ represent a cellular blood component used in selected cases. $^{32-35}$ Similarly, fresh whole blood $\left(2 \times 10^{9}\right.$ lymphocytes per unit) ${ }^{28}$ which represents a possible therapy for trauma resuscitation, ${ }^{36,37}$ should cause the complication due to a recognized decrease of lymphocytes activity after 2 weeks. ${ }^{2}$

Further risk categories may include: non-hodgkin lymphoma treated with novel drugs which impact on the cellular immune system $^{38}$ and acute leukemia which receive purine analogs (e.g. clofarabine and fludarabine)..$^{11-14}$

In addition, in some cases it is hard to confirm the clinical suspect of TA-GVHD (due to attenuated manifestations of the syndrome, confounding factors (infections, autoimmunity), techinical issues of HLA type (pancytopenia)).

\section{Conclusions}

In populations in which more homogeneity of HLA exists, such as documented in Japan, a stricter policy regarding irradiation of cellular blood products is successful. ${ }^{29}$ Higher risk categories for TAGVHD are recipients of haematopoietic stem cell transplantation, severe cellular immunodeficient patients, fetuses and neonates who receive intrauterin transfusions, immunocompetent patients who receive cellular components from blood relatives. ${ }^{11-14}$

Controversies remain regard which cellular blood products are more commonly involved in the reaction and additional risk categories for TA-GVHD 27,38 Haemovigilance, a systematic surveillance of adverse reactions and adverse events related to transfusion, is an effective tool for improving transfusion practice internationally. ${ }^{39,40}$

The gold standard procedure to prevent this complication is 25 gamma or $\mathrm{x}$ irradiation of blood components. ${ }^{11-14}$ New preventive treatments with pathogen inactivation appear effective against proliferating white blood cells and T cells. ${ }^{18,19}$ Further clinical and biological studies are necessary to better characterize immunocompetence of $\mathrm{T}$ cells and compare preventive approaches for TA-GVHD. ${ }^{41-44}$

\section{References}

1. Roback JD, Grossman BJ, Morris T, Millyer CD. Technical manual.17 $7^{\text {th }}$ ed. Bethesda, Maryland: American Association of Blood Banks; 2011.

2. Bordin JO, Heddle NM, Blajchman MA. Biological Effects of leukocytes present in transfused Cellular Blood Products. Blood 1994;84:1703-21.

3. Przepiorka D, LeParc GF, Stovall MA et al. Use of Irradiated Blood Components. Practice Parameter. Am J Clin Pathol 1996;106:6-11.

4. Dwyre DM, Holland PV. Transfusionassociated graft-versus-host disease. Vox Sang 2008; 95: 85-93.

5. Appelbaum FR, Forman SJ, Negrin RS, Blume KG. Thomas' Hematopoietic Cell Transplantation. $4^{\text {th }}$ Ed. Hoboken, NJ: Wiley-Blackwell; 2011.

6. Simon TL, McCullough J, Snyder EL et al. Rossi's Principles of Transf Med. $5^{\text {th }}$ Ed. Hoboken, NJ: Wiley-Blackwell; 2016.

7. Netto GJ, Saad RD. Diagnostic Molecular Pathology an Increasingly Indispensable Tool for the Practicing Pathologist. Arch Pathol Lab Med 2006;130:1339-48.

8. Clark JR, Scott SD, Jack AL et al. Monitoring of chimerism following allogeneic haematopoietic stem cell transplantation (HSCT): Technical recommendations for the use of Short Tandem Repeat (STR) based techniques, on behalf of the United Kingdom National External Quality Assessment Service for Leucocyte Immunophenotyping Chimerism Working Group. $\mathrm{Br} \mathrm{J}$ Haematol 2015;168:26-37.

9. Akay MO, Temiz G, Teke HU et al. Rapid molecular cytogenetic diagnosis of transfusion associated graft-versushost disease by fluorescencent in situ hybridization (FISH). Transf Apher Sci 2008; 38: 189-92.

10. Levine AM, Scadden DT, Zaia JA, and Krishnan A. Hematologic Aspects of HIV/AIDS. Hematol Am Soc Hematol Educ Program 2001:463-78.

11. Australian and New Zealand Society of Blood Transfusion (ANZSBT) LDT. Guidelines for prevention of transfusion-associated graft-versus-host disease (TA-GVHD). $1^{\text {st }}$ Ed. 2011.

12. Treleaven J, Gennery A, Marsh J et al. Guidelines on the use of irradiated blood components prepared by the British Commitee for Standards in Haematology blood transfusion task force. Br J Haematol 2011;152:35-51. 
13. Asay $\mathrm{T}$, Inaba $\mathrm{S}$, Ohto $\mathrm{H}$ et al. Guidelines for irradiation of blood and blood components to prevent posttransfusion graft-vs-host in Japan. Transf Med 2000;10:315-20.

14. New York State Council on Human Blood and Transfusion Services. Guidelines for irradiation of blood and blood components. $4^{\text {th }}$ Ed. 2012.

15. Chu E, De Vita VT. Physicians' Cancer Chemotherapy Drug Manual 2018. Burlington, MA: Jones and Bartlett Learning; 2018.

16. Carson JL, Guyatt G, Heddle NM et al. Clinical Practice Guidelines From the AABB Red Blood Cell Transfusion Thresholds and Storage. JAMA 2016;316:2025-35.

17. Kaufman RM, Djulbegovic B, Gernsheimer $\mathrm{T}$ et al. Platelet Transfusion: A Clinical Practice Guideline From the AABB. Ann Intern Med 2015;162:205-13.

18. Fast LD. Preventing transfusion-associated graft-versus-host disease: state of the art. International Journal of Clinical Transfusion Medicine 2015;2:1-6.

19. Knutson F, Osselaer J, Pierelli L, et al. A prospective, active haemovigilance study with combined cohort analysis of 19175 trabsfusions of platelet components prepared with amotosalen-UVA photochemical treatment. Vox Sanguinis 2015;109:343-52.

20. Gajewski JL, Johnson VV, Sandler SG et al. A review of transfusion practice before, during and after hemopoietic progenitor cell transplantation. Blood 2008;112:3036-47.

21. Weiss B, Hoffmann M, Anders C et al. Gamma-irradiation of blood products following autologous stem cell transplantation: surveillance of the policy of 35 centers. Ann Hemat 2004;83:44-9.

22. Moutuou MM, Page' G, Zaid I, et al. Restoring $\mathrm{T}$ Cell Homeostasis After Allogeneic Stem Cell Transplantation; Principal Limitations and Future Challenges. Front in Immunol 2018,9:1223-37.
23. Xian CL, Jevnikar AM. Transplant Immunology. Hoboken, NJ: WileyBlackwell; 2016.

24. New HV, Berryman J, Bolton-Maggs $\mathrm{PHB}$ et al. Guidelines on transfusion for fetuses, neonates and older children. Brit J Hemato 2016;175:784-828.

25. New HV, Stanworth SJ, Engelfriet CP, et al. Neonatal transfusions. Vox Sang 2009;96:62-85.

26. Janeway CA Jr1, Flavell RA. Immunology at Yale. Immunol Res 1999; 19:105-6.

27. Kopolovic I, Ostro J, Tsubota $\mathrm{H}$ et al. A systematic review of transfusion-associated graft-versus-host disease. Blood 2015;126:406-14.

28. Bahar B, Tormey CA. Prevention of Transfusion-Associated Graft-VersusHost Disease With Blood Product Irradiation. The Past, Present and Future. Arch Pathol Lab Med 2018;142:662-7.

29. Uchida S, Tadokoro K, Takahashi M et al. Analysis of 66 patients definitive with transfusion-associated graft-versus-host disease and the effect of universal irradiation of blood. Transf Med 2013;23:416-22.

30. Serious Hazards of Transfusion (SHOT) Steering Group. The 2012 annual SHOT report. 2013.

31. Bashir S, Naik F, Cardigan R, Thomas S. Effect of X-irradiation on the quality of red cell concentrates. Vox Sang 2011;101:200-7.

32. Zhu M, Xu W, Wang BL, Su H. Hemostatic function and transfusion efficacy of apheresis platelets concetrates treated with gamma irradiation in use for thrombocytopenic patients. Transfus Med Hemother 2014;41:18996.

33. Estcourt LJ, Stanworth SJ, Hopewell S et al. Granulocyte transfusions for treating infections in people with neutropenia or neutrophil dysfunction. Cochrane Database Syst Rev 2016; doi:10.1002/ 14651858.

34. Pammi M, Brocklehurst P. Granulocyte transfusions for neonates with confirmed or suspected sepsis and neutropenia (Review) Cochrane Database Syst Rev. 2011; doi: 10.1002/14651858.

35. Klein K, Castillo B. Historical Perspective, Current Status and Ethical issue in Granulocyte Transfusion. Ann of Clin and Lab Sci 2017 47:501-7.

36. McDaniel LM, Etchill EW, Raval JS, Neal MD. State of the art: massive transfusion. Transf Med 2014;24:13844.

37. McQuilten ZK, Crighton G, Brunskill S et al. Optimal Dose, Timing and Ratio of Blood Products in Massive Transfusion: Results from a Systematic Review. Transf Med Rev 2018;32:6-15.

38. Morrissey KM, Yuraszeck TM, Li CC et al. Immunotherapy and Novel Combinations in Oncology: Current Landscape, Challenges, and Opportunities. Clin Transl Sci 2016;89104.

39. Stainsby D. Haemovigilance in the United Kingdom and Europe. The Hematol J 2004;5:S175-8.

40. Politis C, Wiersum JC, Richardson C et al. The International Haemovigilance Network Database for the Surveillance of Adverse Reactions and Events in Donors and Recipients of Blood Components: technical issues and results. Vox Sang 2016;111:409-17.

41. Pritchard AE, Shaz BH. Survey of Irradiation Practice for the Prevention of Transfusion-Associated Graft-versus-Host Disease. Arch Pathol Lab Med 2016;140:1092-7.

42. Alter HJ, Klein HG. The hazards of blood transfusion in historical perspective. Blood 2008;112:2617-26.

43. Delaney M, Wendel S, Bercovitz RS et al. Transfusion reactions: prevention, diagnosis, and treatment. Lancet 2016;388:2825-36.

44. Herndler-Brandstetter D, Ishigame $\mathrm{H}$ and Flavell RA. How to define biomarkers of human $\mathrm{T}$ cell aging and immunocompetence? Front Immunol 2013;4:1-4. 